\title{
THEORETICAL INVESTIGATION OF ENERGY SPECTRA OF TUNGSTEN IONS $\mathbf{W}^{29+}-\mathbf{W}^{34+*}$
}

\author{
P. Bogdanovich and R. Karpuškienè \\ Institute of Theoretical Physics and Astronomy of Vilnius University, A. Goštauto 12, LT-01108 Vilnius, Lithuania \\ E-mail: karra@itpa.It
}

Received 7 June 2007

\begin{abstract}
Since 2007 the Institute of Theoretical Physics and Astronomy of Vilnius University participates in the international project on thermonuclear fusion investigation ITER. Tungsten is one of the constructional materials used to cover the inner walls of tokamaks. In the framework of ITER project the task of both theoretical and experimental research of spectral characteristics of various tungsten ions was posed. The ground configuration of the investigated ions $\mathrm{W}^{29+}, \mathrm{W}^{30+}, \mathrm{W}^{31+}, \mathrm{W}^{32+}, \mathrm{W}^{33+}$, $\mathrm{W}^{34+}$ is [Ni] $4 s^{2} 4 p^{6} 4 d^{N}$ (here the number of $d$-electrons $N$ is from 9 to 4 ).

Preliminary calculations of energy spectra of highly charged tungsten ions with filling $4 d$ shell reveal that the task of obtaining the characteristics of resonant transitions with account of relativistic and correlation effects would not be very complicated, since only two excited configurations $4 s^{2} 4 p^{5} 4 d^{N+1}$ and $4 s^{2} 4 p^{6} 4 d^{N-1} 4 f$ are strongly interacting. The emission band of the resonant transitions intersects with multiple emission lines that correspond to the transitions from the excited configurations of the same parity as the ground one to the mentioned two configurations. It will be essentially more difficult to obtain the transition characteristics in this case, since the initial configurations form a group with a very large number of levels.
\end{abstract}

Keywords: tungsten, configuration interaction, highly charged ions

PACS: 31.15.Ar, 31.25.Eb, 31.25.Jf

\section{Introduction}

Vilnius school of a theory of an atom established by Prof. A. Jucys exists for almost 60 years now. During this time many methods of theoretical investigation have been created, wide experience of practical application of the methods has been accumulated. From the beginning of nineties, when personal computers had been started to exploit for calculations, the possibility to use widely known computer codes for investigation of spectral characteristics of atoms and ions appeared. A whole series of effective methods and original programs have been created after mastering the world experience. The acknowledgement of the high level of Vilnius theorists reflects in participation of the Institute of Theoretical Physics and Astronomy of Vilnius University in the international project on thermonuclear fusion investigation ITER since 2007.

Tungsten is one of the constructional materials used to cover the inner walls of tokamaks. This element can be detached from the walls and various ions of this atom appear in the plasma. The radiation of tung-

\footnotetext{
* The report presented at the 37th Lithuanian National Physics Conference, 11-13 June 2007, Vilnius, Lithuania
}

sten ions joins the total spectrum of the thermonuclear plasma in various regions of wavelengths and this should be kept in mind while performing spectral investigation of such plasmas. The spectral characteristics of tungsten ions are not properly analysed since the production and spectral investigation of such highly ionized atoms demands very high temperatures and complicated experiments. In the framework of ITER project the task of both theoretical and experimental research of spectral characteristics of various tungsten ions was posed. Diverse experimental methods are applied to investigate different tungsten ions. The detailed description of the performed researches is available in [1-3]. Within the experimental investigations the main attention is paid to the ions of middle ionization degree with intensive radiation in the region from 45 to $70 \AA$. The spectra of these ions are composed from a multitude of resolved lines, which form bright emission bands. It is known that such quasicontinuum emission bands originate from mostly $\Delta n=0$ electric transitions within the $n=4$ shell, though $\Delta n=1$ transitions are also known to create continuum bands. In order to perform the successful interpretation of the obtained experimental results the theoretical data are 
necessary. Generation of such theoretical data is a very challenging task due to the outstandingly large number of levels and even bigger number of possible transitions between the levels. The purpose of this paper is determination of the configurations that are necessary to investigate, so that the transitions between them would correspond to the needed wavelength interval, and obtaining preliminary data on the energy spectra of the ions under investigation.

\section{Discussion of the calculation results}

The ground configuration of the investigated ions is [Ni] $4 s^{2} 4 p^{6} 4 d^{N}$, here $N$ (number of $d$-electrons) varies from 9 to 4 depending on the degree of ionization. As follows from the experimental data [1,2], the most intensive radiation corresponds to the resonant transitions from excited configurations $4 s^{2} 4 p^{5} 4 d^{N+1}$ and $4 s^{2} 4 p^{6} 4 d^{N-1} 4 f$ to the ground configuration. The transitions between the excited configurations are no less important, too. Since there are no complete data on the highly excited configurations, all configurations with the energy lower than that of the configuration $4 s^{2} 4 p^{6} 4 d^{N-1} 5 g$ have been investigated.

The non-relativistic radial orbitals (RO) obtained by solving Hartree-Fock equations [4] have been used in performing the investigation. The equation for the ground configuration has been solved, and after that the RO of all excited electrons have been obtained within the frozen core field approximation. The relativistic effects are taken into account within the Breit-Pauli approach $[5,6]$.

The ionization degrees under investigation $(+29$, $\ldots,+34)$ are high, therefore the correlation effects appearing due to virtual excitations are comparatively weak. Thus only the superposition of the lower really existing configurations is used in calculations, i.e. only the configurations being examined are included into superposition. These configurations are obtained from the ground configuration by excitation of electrons from $4 s, 4 p$, and $4 d$ levels. Besides the mentioned program and our original computer codes for calculation and diagonalization of energy operator matrices, the program for calculation of angular parts of matrix elements of the Breit-Pauli energy matrix [7] was used.

The investigated configurations of each ion are divided into two groups according to their parity. The first group of the investigated configurations is formed from the ones with the same parity as the ground configuration:

$$
\begin{aligned}
& 4 s^{2} 4 p^{6} 4 d^{N}, \\
& 4 s 4 p^{6} 4 d^{N+1}, \\
& 4 s^{2} 4 p^{6} 4 d^{N-1} 5 l(l=s, d, g), \\
& 4 s^{2} 4 p^{4} 4 d^{N+2}, \\
& 4 s^{2} 4 p^{5} 4 d^{N} 4 f \\
& 4 s^{2} 4 p^{6} 4 d^{N-2} 4 f^{2}, \\
& 4 s^{2} 4 p^{5} 4 d^{N} 5 p \\
& 4 s^{2} 4 p^{6} 4 d^{N-2} 4 f 5 p \\
& 4 p^{6} 4 d^{N+2} \\
& 4 s 4 p^{5} 4 d^{N+1} 4 f \\
& 4 s 4 p^{4} 4 d^{N+3}
\end{aligned}
$$

The second group of the investigated configurations is formed from the configurations of the same parity as the first excited one:

$$
\begin{aligned}
& 4 s^{2} 4 p^{5} 4 d^{N+1}, \\
& 4 s^{2} 4 p^{6} 4 d^{N-1} 4 f, \\
& 4 s^{2} 4 p^{6} 4 d^{N-1} 5 l(l=p, f), \\
& 4 s 4 p^{6} 4 d^{N} 4 f, \\
& 4 s^{2} 4 p^{6} 4 d^{N-2} 4 f 5 s, \\
& 4 s^{2} 4 p^{4} 4 d^{N+1} 4 f, \\
& 4 s^{2} 4 p^{5} 4 d^{N-1} 4 f^{2}, \\
& 4 s^{2} 4 p^{5} 4 d^{N} 5 s, \\
& 4 s 4 p^{5} 4 d^{N+2}, \\
& 4 s^{2} 4 p^{3} 4 d^{N+3} .
\end{aligned}
$$

The influence of the energetically close configurations on each other and their mixing is successfully taken into account when the configurations are investigated not as single ones but as a group of the same parity. Although the number of configurations in both groups is comparatively small, the total number of their levels is rather large. Even though these spectra parameters do not exceed the possibilities of existing programs and used computers, the performed calculations have demanded much computer time for diagonalization of energy matrices. Obtaining the energy spectra of separate groups of some ions has necessitated more than a week of a PC calculation time. It happened because the obtained matrices contain many large off-diagonal matrix elements and initial $L S$-coupling functions are strongly mixed within the obtained multiterm eigenfunctions, as seen from the data below.

The preliminary energy spectra of tungsten ions are presented in the figures. On the left side in the figures there is the first group of the configurations, on the right side is the second one. As it follows from the experimental works [1-3], the investigated ions radiate most 


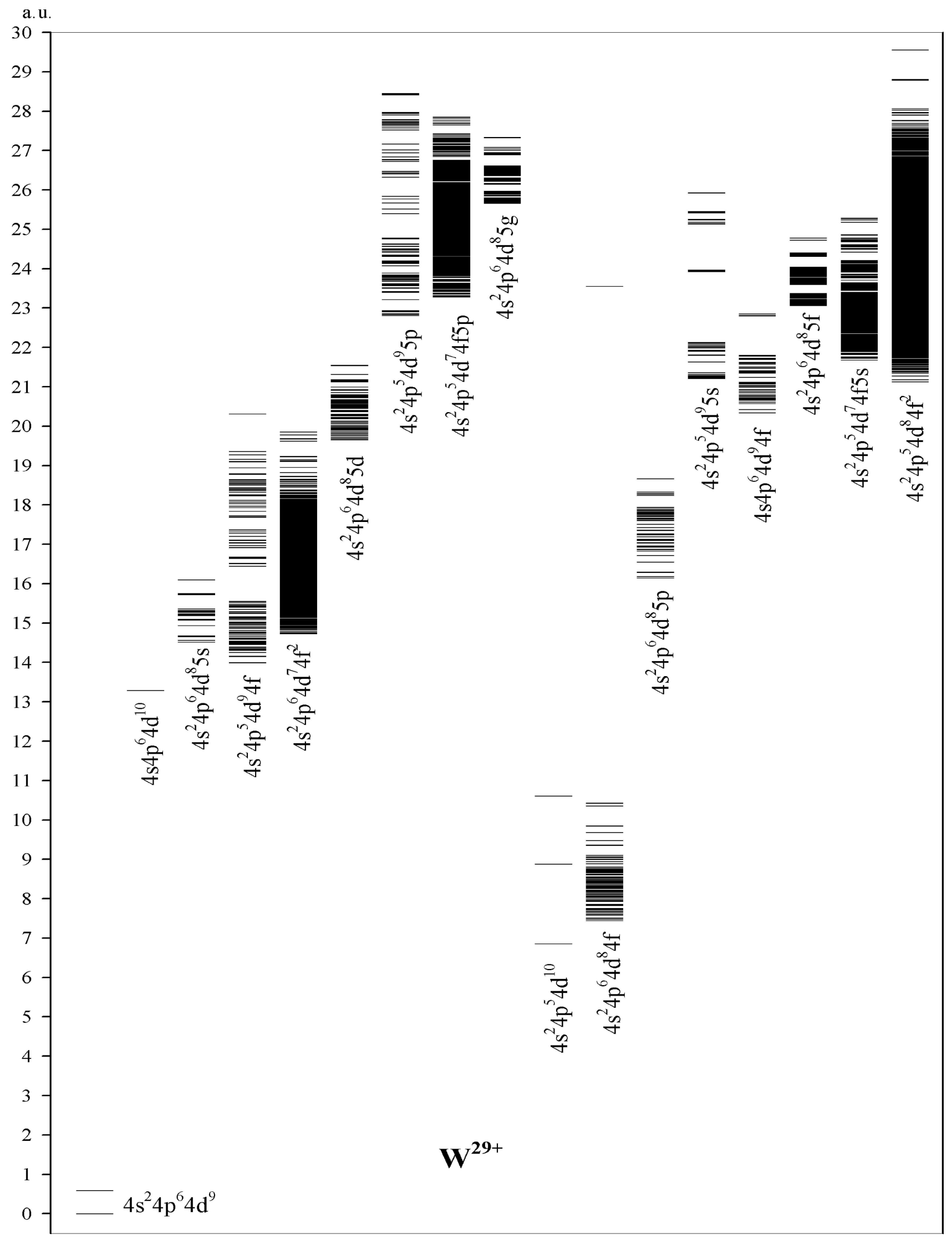

Fig. 1. Energy spectra of $\mathrm{W}^{29+}$. 


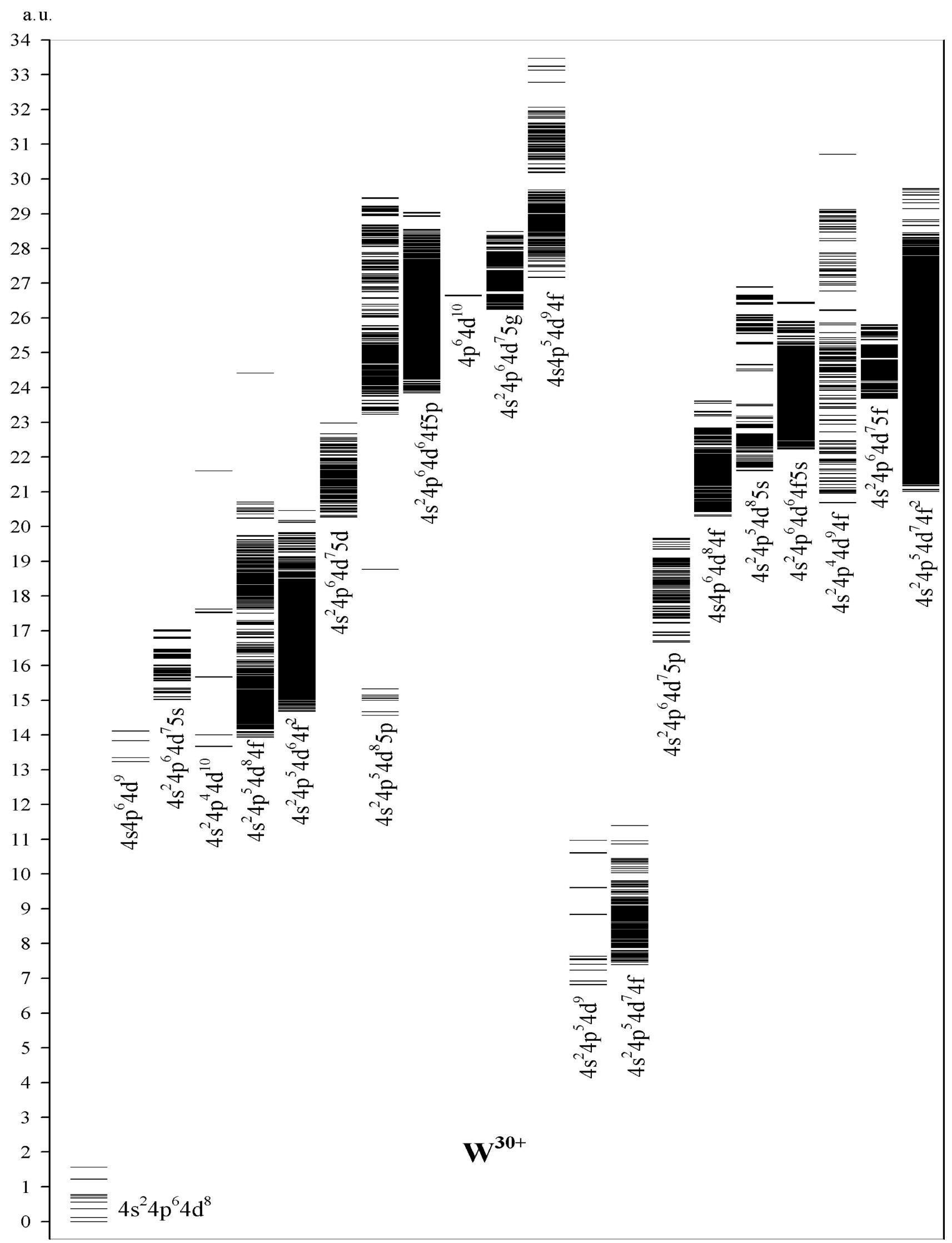

Fig. 2. Energy spectra of $\mathrm{W}^{30+}$. 


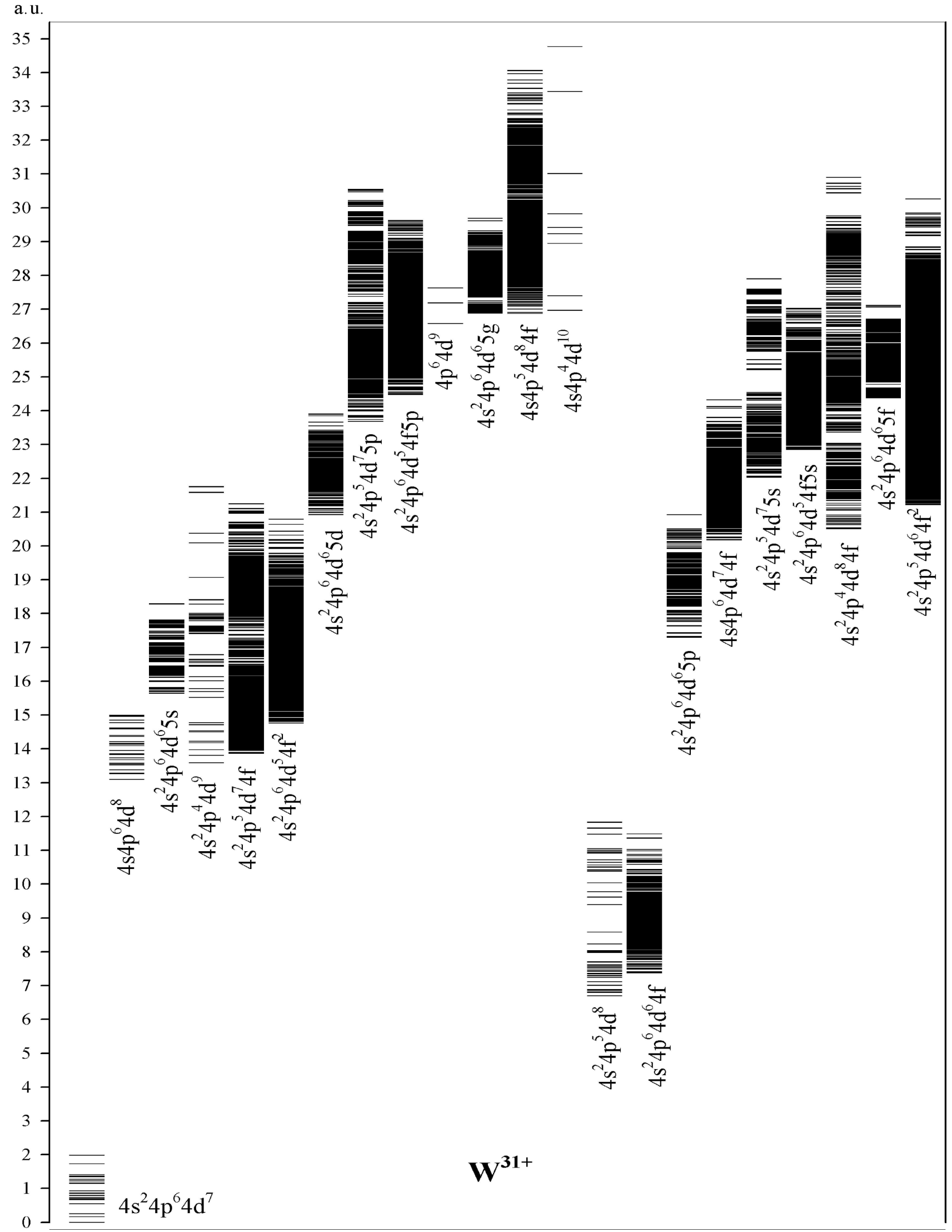

Fig. 3. Energy spectra of $\mathrm{W}^{31+}$. 


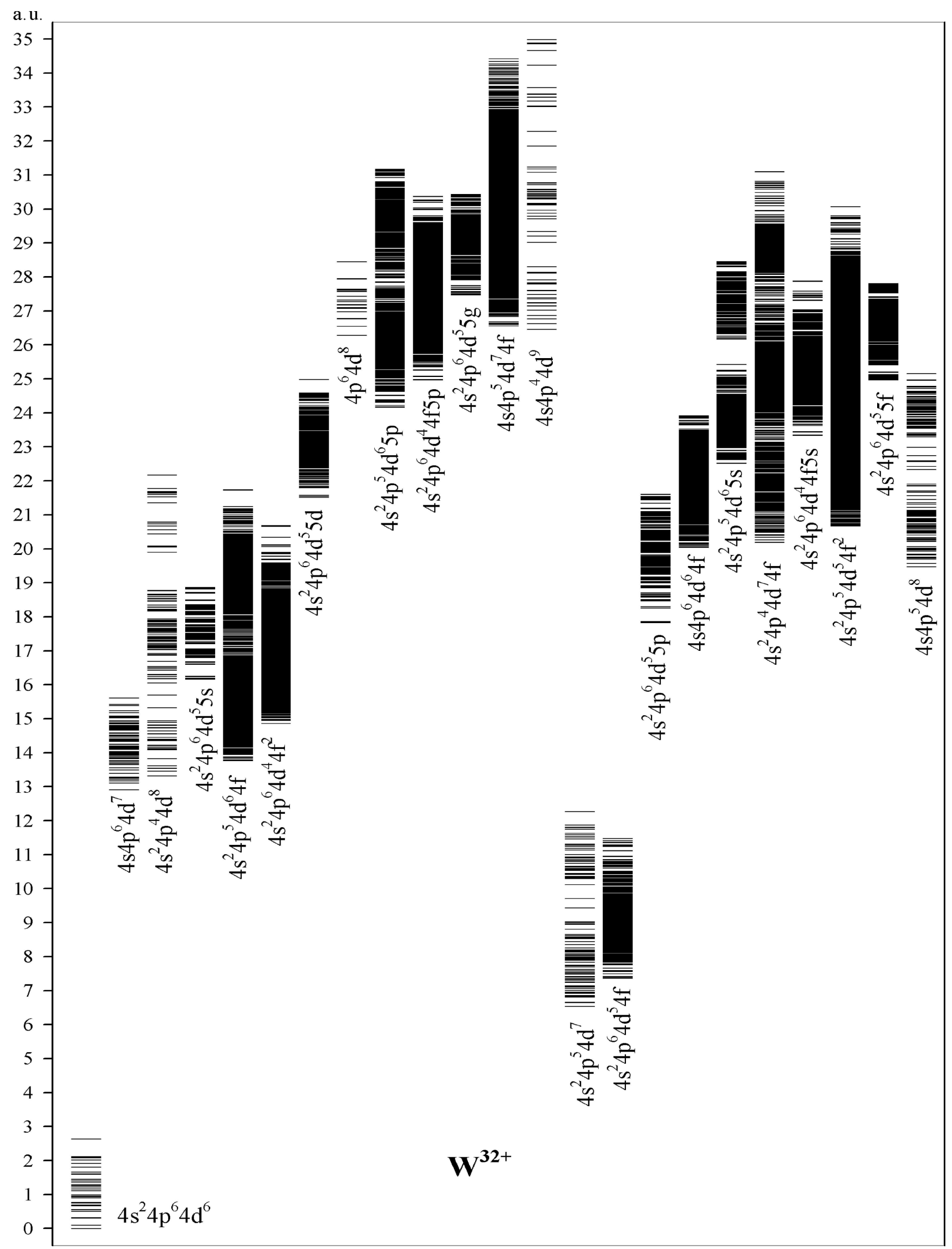

Fig. 4. Energy spectra of $\mathrm{W}^{32+}$. 


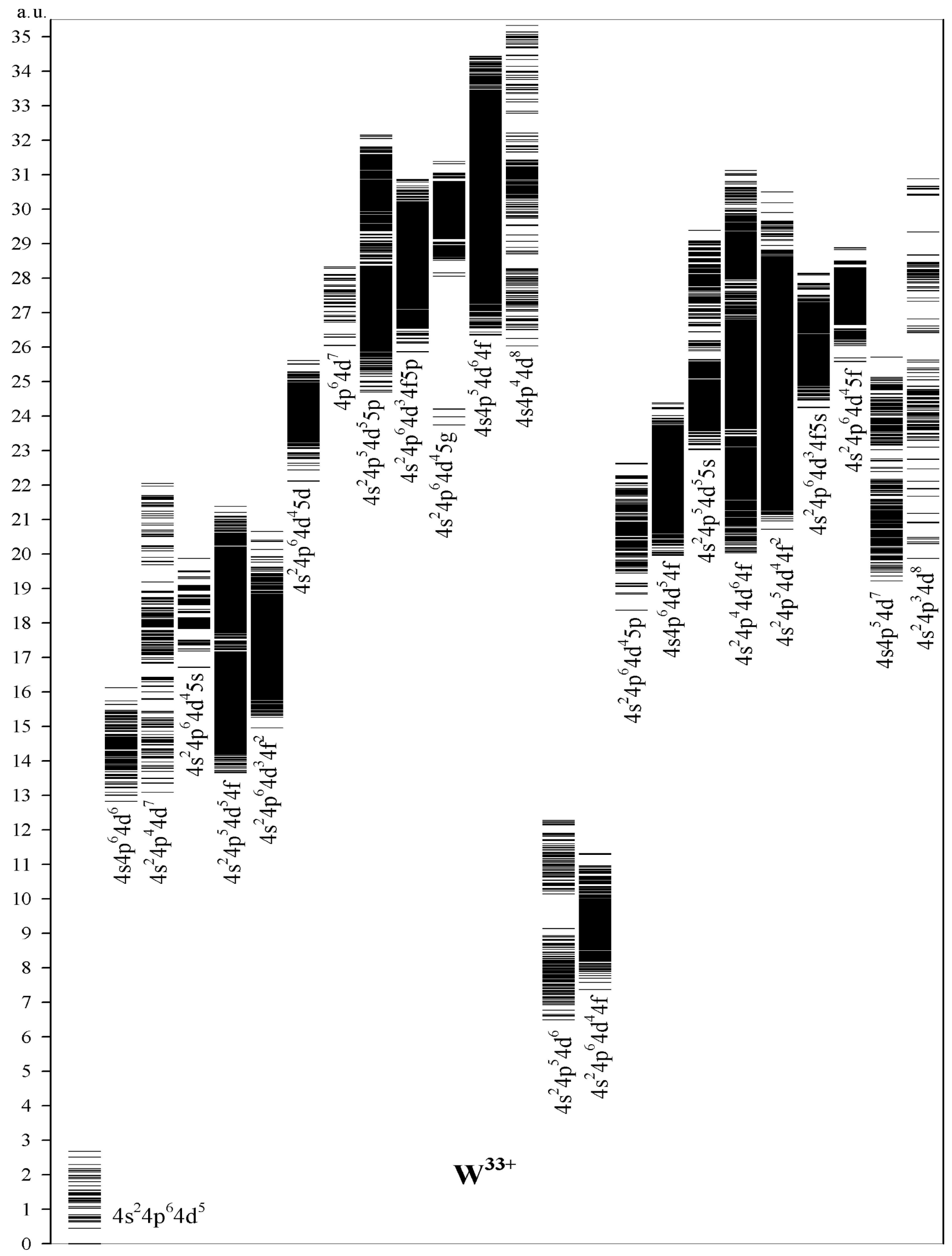

Fig. 5. Energy spectra of $\mathrm{W}^{33+}$. 


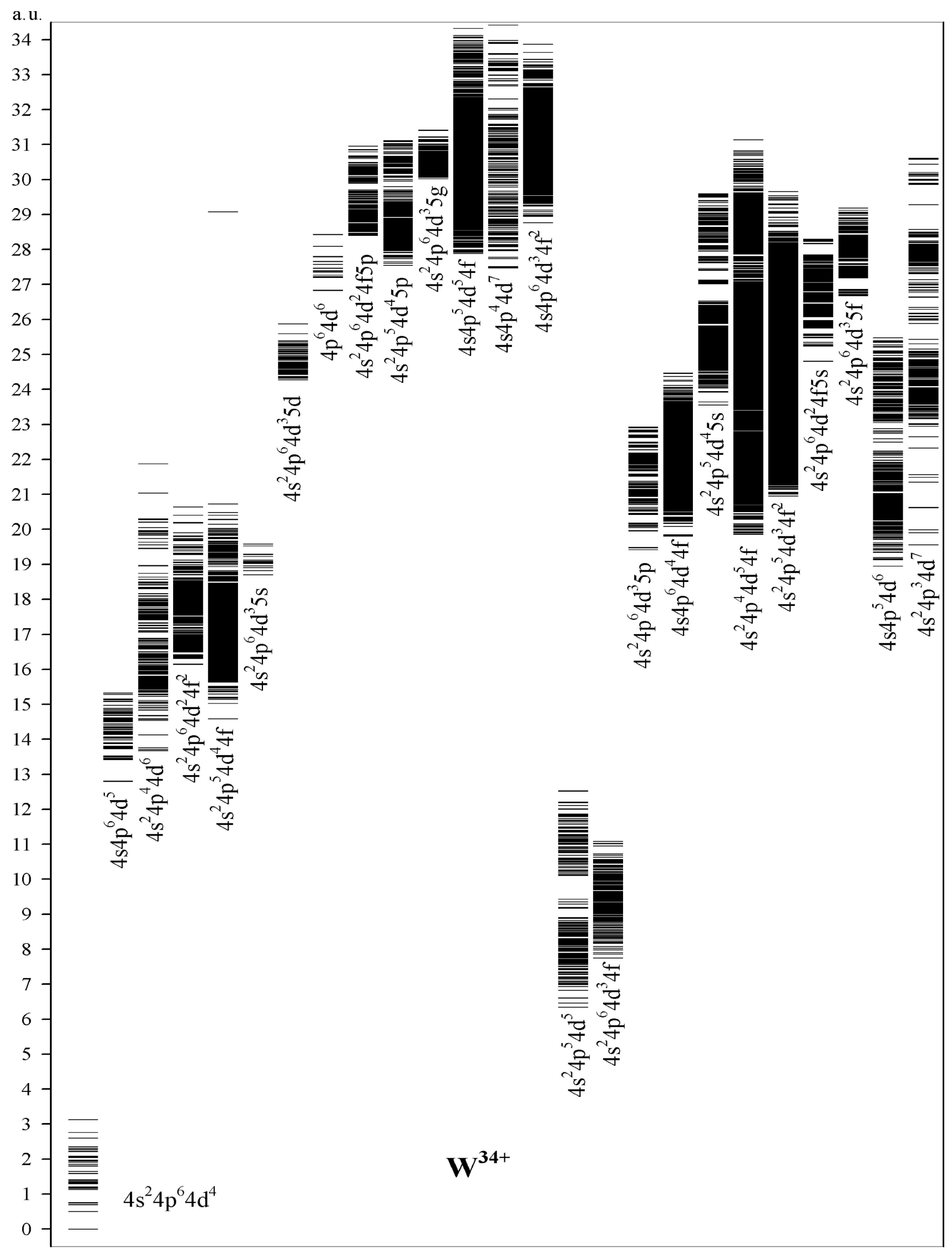

Fig. 6. Energy spectra of $\mathrm{W}^{34+}$. 
Table 1. Number of levels of investigated configurations: $K$ is the real number, $K^{\prime}$ is a number assigned after diagonalization.

\begin{tabular}{|c|c|c|c|c|c|c|c|c|c|c|c|c|}
\hline \multirow[b]{2}{*}{ Configuration } & \multicolumn{2}{|c|}{$\mathrm{W}^{34+}(N=4)$} & \multicolumn{2}{|c|}{$\mathrm{W}^{33+}(N=5)$} & \multicolumn{2}{|c|}{$\mathrm{W}^{32+}(N=6)$} & \multicolumn{2}{|c|}{$\mathrm{W}^{31+}(N=7)$} & \multicolumn{2}{|c|}{$\mathrm{W}^{30+}(N=8)$} & \multicolumn{2}{|c|}{$\mathrm{W}^{29+}(N=9)$} \\
\hline & $K$ & $K^{\prime}$ & $K$ & $K^{\prime}$ & $K$ & $K^{\prime}$ & $K$ & $K^{\prime}$ & $K$ & $K^{\prime}$ & $K$ & $K^{\prime}$ \\
\hline $4 s^{2} 4 p^{6} 4 d^{N}$ & 34 & 34 & 37 & 37 & 34 & 34 & 19 & 19 & 9 & 9 & 2 & 2 \\
\hline $4 s 4 p^{6} 4 d^{N+1}$ & 74 & 75 & 63 & 132 & 38 & 80 & 16 & 24 & 4 & 4 & 1 & 1 \\
\hline $4 s^{2} 4 p^{4} 4 d^{N+2}$ & 444 & 458 & 261 & 223 & 111 & 124 & 28 & 54 & 5 & 7 & - & - \\
\hline $4 s^{2} 4 p^{6} 4 d^{N-2} 4 f^{2}$ & 457 & 509 & 1149 & 1595 & 1982 & 2221 & 2334 & 2337 & 1982 & 1918 & 1149 & 1127 \\
\hline $4 s^{2} 4 p^{5} 4 d^{N} 4 f$ & 2022 & 1953 & 2382 & 1824 & 2022 & 1619 & 1180 & 1022 & 472 & 481 & 113 & 126 \\
\hline $4 s^{2} 4 p^{6} 4 d^{N-1} 5 s$ & 38 & 40 & 63 & 144 & 74 & 183 & 63 & 184 & 38 & 90 & 16 & 24 \\
\hline $4 s^{2} 4 p^{6} 4 d^{N-1} 5 \mathrm{~d}$ & 168 & 168 & 276 & 276 & 332 & 332 & 276 & 276 & 168 & 169 & 67 & 68 \\
\hline $4 p^{6} 4 d^{N+2}$ & 34 & 34 & 19 & 42 & 9 & 21 & 2 & 5 & 1 & 2 & - & - \\
\hline $4 s^{2} 4 p^{6} 4 d^{N-2} 4 f 5 p$ & 472 & 570 & 1180 & 1369 & 2022 & 1971 & 2382 & 2256 & 2022 & 1873 & 1180 & 1141 \\
\hline $4 s^{2} 4 p^{5} 4 d^{N} 5 p$ & 1038 & 1011 & 1208 & 1030 & 1038 & 929 & 613 & 603 & 256 & 322 & 65 & 90 \\
\hline $4 s^{2} 4 p^{6} 4 d^{N-1} 5 g$ & 228 & 402 & 389 & 637 & 466 & 679 & 389 & 516 & 228 & 307 & 88 & 102 \\
\hline $4 s 4 p^{6} 4 d^{N-1} 4 f^{2}$ & 4710 & 4423 & - & - & - & - & - & - & - & - & - & - \\
\hline $4 s 4 p^{5} 4 d^{N+1} 4 f$ & 515 & 545 & 3939 & 3641 & 2353 & 2283 & 924 & 928 & 226 & 229 & - & - \\
\hline $4 s 4 p^{4} 4 d^{N+3}$ & 2275 & 2287 & 211 & 227 & 56 & 61 & 8 & 10 & - & - & - & - \\
\hline $4 s^{2} 4 p^{5} 4 d^{N+1}$ & 214 & 200 & 180 & 170 & 110 & 111 & 45 & 49 & 12 & 13 & 2 & 3 \\
\hline $4 s^{2} 4 p^{6} 4 d^{N-1} 4 f$ & 206 & 220 & 346 & 356 & 416 & 415 & 346 & 342 & 206 & 205 & 81 & 80 \\
\hline $4 s^{2} 4 p^{6} 4 d^{N-1} 5 p$ & 110 & 249 & 180 & 243 & 214 & 226 & 180 & 180 & 110 & 110 & 45 & 45 \\
\hline $4 s 4 p^{6} 4 d^{N} 4 f$ & 692 & 1632 & 815 & 1949 & 692 & 1633 & 404 & 1001 & 162 & 307 & 39 & 41 \\
\hline $4 s^{2} 4 p^{5} 4 d^{N} 5 s$ & 360 & 852 & 417 & 1103 & 360 & 1075 & 213 & 588 & 90 & 212 & 23 & 36 \\
\hline $4 s^{2} 4 p^{4} 4 d^{N+1} 4 f$ & 5886 & 3939 & 4905 & 3000 & 2914 & 1683 & 1140 & 665 & 278 & 171 & - & - \\
\hline $4 s^{2} 4 p^{5} 4 d^{N-1} 4 f^{2}$ & 6748 & 6596 & 11444 & 9973 & 13726 & 11324 & 10845 & 8653 & 6486 & 5486 & 2506 & 2278 \\
\hline $4 s^{2} 4 p^{6} 4 d^{N-2} 4 f 5 s$ & 162 & 546 & 404 & 1404 & 692 & 1922 & 815 & 1921 & 692 & 1317 & 404 & 551 \\
\hline $4 s^{2} 4 p^{6} 4 d^{N-1} 5 \mathrm{f}$ & 206 & 340 & 346 & 746 & 416 & 1086 & 346 & 935 & 206 & 421 & 81 & 147 \\
\hline $4 s 4 p^{5} 4 d^{N+2}$ & 360 & 411 & 213 & 301 & 90 & 155 & - & - & - & - & - & - \\
\hline $4 s^{2} 4 p^{3} 4 d^{N+3}$ & 350 & 309 & 141 & 146 & - & - & - & - & - & - & - & - \\
\hline Total number of levels & 27803 & 27803 & 30568 & 30568 & 30167 & 30167 & 22568 & 22568 & 13653 & 13653 & 5862 & 5862 \\
\hline
\end{tabular}

intensively in the region between 4 and $5 \mathrm{~nm}$. These wavelengths correspond to the transitions between the levels energetically apart by approximately $10 \mathrm{a}$. u. On the vertical axis the energy is presented in atomic units to facilitate the discrimination of configurations participating in such transitions.

It is seen from the presented figures that the mentioned wavelength interval corresponds to the resonance transitions from the excited configurations $4 s^{2} 4 p^{5} 4 d^{N+1}$ and $4 s^{2} 4 p^{6} 4 d^{N-1} 4 f$ to the ground one. It has been anticipated that besides the mentioned transitions the transitions from the higher configuration group (of the same parity as the ground configuration) to the mentioned two excited configurations take place. The performed calculations confirm that the energy distance between excited configurations of the different parity is also about 10 a. u. However, the situation here is very compli- cated and the calculations of higher excited configuration energy spectra alone demand much computer time. As it is seen from the Figs. 1-6, the configurations $4 s 4 p^{6} 4 d^{N+1}, 4 s^{2} 4 p^{6} 4 d^{N-1} 5 s, 4 s^{2} 4 p^{4} 4 d^{N+2}$, $4 s^{2} 4 p^{5} 4 d^{N} 4 f, 4 s^{2} 4 p^{6} 4 d^{N-2} 4 f^{2}$ form a compact group. The energy spectra of these configurations strongly intersect, consequently, their levels strongly interact, and obtained eigenfunctions essentially deviate from the initial single-configuration $L S$-coupling. After the total diagonalization of the energy matrix it is seen that the mixing of the initial wavefunctions is very strong within the multiterm multiconfiguration functions. The used computer program assigns the levels to one or another configuration formally according to their maximal weight within the multiterm function obtained after the diagonalization. The number of the levels may change within the configuration on account of such formal assignment. There is an obvious example of such 
situation in Fig. 1. In this figure the energy spectrum of the excited configuration $4 s^{2} 4 p^{5} 4 d^{10}$ is presented, where three levels are easily seen instead of two ones. Correspondingly, the energetically close configuration $4 s^{2} 4 p^{6} 4 d^{8} 4 f$ contains one level less.

In Table 1 the numbers of levels of each investigated configuration are presented. The number of levels $K$ shows how many levels one or another configuration must have, and number $K^{\prime}$ denotes how many levels this configuration contains after diagonalization when the levels are formally classified by the highest weight of the multiterm function. As it is seen from the table, the number of levels of some configurations notably grows. For example, the number of levels of configuration $4 s^{2} 4 p^{6} 4 d^{6} 5 s$ of the ion $\mathrm{W}^{31+}$ increases by more than 3 times after diagonalization, and in the case of $4 s 4 p^{6} 4 d^{N+1}$ configuration of $\mathrm{W}^{32+}$ and $\mathrm{W}^{33+}$ ions it more than doubles. The loss of levels is not so obvious as the increase of their numbers, since the levels reduce in the configurations with very large numbers of those. For example, the configuration $4 s^{2} 4 p^{5} 4 d^{5} 4 f$ of $\mathrm{W}^{33+}$ should have had 2382 levels, but after the diagonalization only 1824 levels are assigned to it, i.e. approximately $30 \%$ less than originally.

It is interesting that in the spectra of almost every ion more than one level is identified by the same set of quantum numbers. Some sets of quantum numbers appear even more than five times. The level $4 s^{2} 4 p^{6} 4 d^{5}\left({ }^{6} \mathrm{~S}\right) 4 f\left({ }^{7} \mathrm{~F}\right) 5 s{ }^{8} \mathrm{~F}_{5 / 2}$ of $\mathrm{W}^{31+}$ ion repeats most of all (14 times). This means that within the multiterm functions of these levels not a single expansion coefficient exceeds 0.267 by its absolute value and corresponding weight is not more than 0.0714. Although the mentioned facts strongly influence the number of assigned levels of particular configurations, the total number of levels of the investigated group of configurations remains the same.

It is obvious that the classification of the levels by $L S$ terms poorly fits the investigated states of tungsten. It is a usual situation for such highly ionized atoms. At the same time, the significant changes (in some cases even by several times) of the number of levels assigned to the particular configuration show that even the using of $j j$-coupling would hardly help, since in the investigated case the concept of configuration is inappropriate in describing the excited states.

\section{Conclusion}

The preliminary calculations of energy spectra of highly charged tungsten ions with filling $4 d$ electron shell reveal that the task of obtaining the characteristics of resonant transitions with account of relativistic and correlation effects would not be very complicated, since only two excited configurations $4 s^{2} 4 p^{5} 4 d^{N+1}$ and $4 s^{2} 4 p^{6} 4 d^{N-1} 4 f$ are strongly interacting. The emission band of the resonant transitions intersects with the multiple emission lines that correspond to the transitions from the excited configurations of the same parity as the ground one to the mentioned two configurations. It will be essentially more difficult to obtain the transition characteristics in this case, since the initial configurations form a group with a very large number of levels. The energies of these levels lie within a narrow interval. This implies extreme correlation effects, which lead to a situation where the investigated levels cannot be unambiguously assigned to the particular configuration. A chosen precision of calculation of the corresponding matrix elements influences the interaction of the energetically close levels. The correct account of the relativistic effects makes significant differences in the accuracy of the mentioned matrix elements.

Thus the conclusion arises that the energy spectra and transition characteristics of highly charged tungsten ions should be calculated within either Dirac-Fock or quasirelativistic approaches.

\section{Acknowledgements}

These calculations have been performed using the resources of the European Commission project RI 026715 BalticGrid and the LitGrid project.

This work, partially supported by the European Communities under the contract of Association between EURATOM/LEI FU06-2006-00443, was carried out within the framework of the European Fusion Development Agreement. The views and opinions expressed herein do not necessarily reflect those of the European Commission.

\section{References}

[1] C. Biedermann, R. Radtke, J.-L. Schwob, P. Mandelbaum, R. Doron, T. Fuchs, and G. Fußmann, EUV spectroscopy of highly charged tungsten ions relevant to hot plasmas, Phys. Scripta T92, 85 (2001).

[2] R. Radtke, C. Biedermann, J.L. Schwob, P. Mandelbaum, and R. Doron, Line and band emission from tungsten ions with charge $21+$ to $45+$ in the $45-70 \AA$ range, Phys. Rev. A 64, 012720-1 (2001). 
[3] T. Pütterich, R. Neu, C. Biedermann, R. Radtke, and ASDEX Upgrade Team, Disentangling the emissions of highly ionized tungsten in the range 4-14 nm, J. Phys. B 38, 3071 (2005).

[4] C. Froese Fischer, A general Hartree-Fock program, Comput. Phys. Commun. 43, 355 (1987).

[5] H.A. Bethe and E.E. Salpeter, Quantum Mechanics of One- and Two-Electron Atoms (Springer-Verlag, Berlin-Götingen-Heidelberg, 1957).

[6] Z. Rudzikas, Theoretical Atomic Spectroscopy (Cambridge University Press, 1997).

[7] G. Gaigalas, The library of subroutines for calculation of matrix elements of two-particle operators for many electron atoms, Lithuanian J. Phys. 42, 73 (2002).

\title{
TEORINIS VOLFRAMO JONU $\mathbf{W}^{29+}-\mathrm{W}^{34+}$ ENERGIJOS SPEKTRU TYRIMAS
}

\author{
P. Bogdanovičius, R. Karpuškienė
}

VU Teorinès fizikos ir astronomijos institutas, Vilnius, Lietuva

\section{Santrauka}

Nuo $2007 \mathrm{~m}$. Vilniaus universiteto Teorinès fizikos ir astronomijos institutas dalyvauja tarptautiniame termobranduolinès sintezès tyrimo projekte ITER. Šiame projekte iškelta užduotis ištirti volframo jonu $\mathrm{W}^{29+}, \mathrm{W}^{30+}, \mathrm{W}^{31+}, \mathrm{W}^{32+}, \mathrm{W}^{33+}$ ir $\mathrm{W}^{34+}$ energijos spektrus ir kitas spektrines charakteristikas. Tiriamu jonu pagrindinè konfigūracija yra $[\mathrm{Ni}] 4 s^{2} 4 p^{6} 4 d^{N}$, kur $N$ ( $d$ elektronu skaičius) yra nuo 9 iki 4 . Remiantis eksperimentiniais duomenimis, intensyviausią spinduliavimą atitinka rezonansiniai šuoliai iš sužadintų konfigūracijų $4 s^{2} 4 p^{5} 4 d^{N+1}$ ir $4 s^{2} 4 p^{6} 4 d^{N-1} 4 f$ i pagrindinę konfigūraciją.

Atlikti preliminarūs daugiakrūvių volframo jonų su besipildančiu $4 d$ sluoksniu energijos spektrų skaičiavimai parodè, kad rezonansinių šuolių charakteristikų gavimas atsižvelgiant $i$ reliatyvistinius ir koreliacinius efektus nebūtų labai sudètingas, kadangi stip- riai maišosi tik dvi sužadintos konfigūracijos. Rezonansiniu šuolių emisijos juosta persikloja su gausiomis emisijos linijomis, kurias atitinka šuoliai iš aukščiau esančiu sužadintų konfigūraciju i minètas dvi sužadintas konfigūracijas. Šių šuolių charakteristikų gavimas bus iš esmès sudètingesnis, nes pradinès konfigūracijos sudaro grupę su ypač daug lygmenų. Šių lygmenų energijos yra nedideliame intervale, ir tai sukelia itin didelius koreliacinius efektus, dèl kurių nagrinejjami lygmenys negali būti vienareikšmiškai priskirti konkrečiai konfigūracijai. Energetiškai artimų lygmenų tarpusavio sąveiką lemia pasirenkamas atitinkamu matricinių elementu skaičiavimo tikslumas, kuriam svarbiausia yra korektiškas atsižvelgimas $\mathfrak{i}$ reliatyvistinius efektus nagrinejjamuose daugiakrūviuose jonuose. Taigi, kyla išvada, kad daugiakrūvių volframo jonu energijos spektrus ir šuolių charakteristikas reiktu skaičiuoti Dirako ir Foko arba kvazireliatyvistiniame artinyje. 